\title{
Correction to: Inhibition of 3-hydroxy-3- methyl-glutarylcoenzyme A reductase enzyme by dipeptides identified in dry- cured ham
}

Alejandro Heres, Leticia Mora ${ }^{*}$ and Fidel Toldrá

Correction to: Food Prod Process Nutr 3, 18 (2021) https://doi.org/10.1186/s43014-021-00058-w

Following the publication of the original article (Heres et al., 2021), the authors identified a typesetting error in Fig. 1, and Fig. 2. The deviation letters are missing in both figures.

The correct figures have been included in this correction, and the original article has been corrected.

Published online: 25 August 2021

\section{Reference}

Heres, et al. (2021). Food Production, Processing and Nutrition, 3, 18.

(c) The Author(s). 2021 Open Access This article is licensed under a Creative Commons Attribution 4.0 International License, which permits use, sharing, adaptation, distribution and reproduction in any medium or format, as long as you give appropriate credit to the original author(s) and the source, provide a link to the Creative Commons licence, and indicate if changes were made. The images or other third party material in this article are included in the article's Creative Commons licence, unless indicated otherwise in a credit line to the material. If material is not included in the article's Creative Commons licence and your intended use is not permitted by statutory regulation or exceeds the permitted use, you will need to obtain permission directly from the copyright holder. To view a copy of this licence, visit http://creativecommons.org/licenses/by/4.0/. 

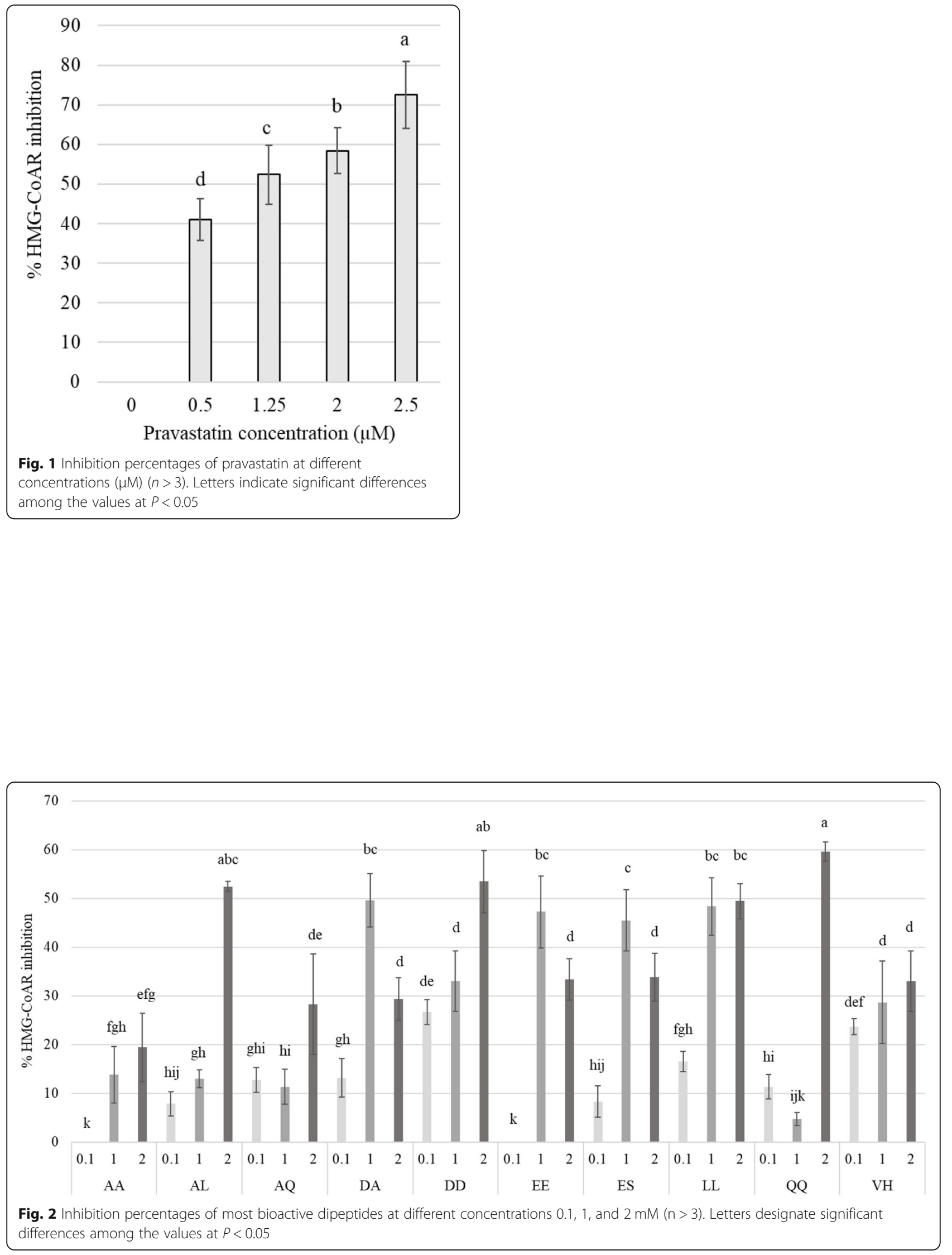